УДК 378.147 .88

DOI:

Вікторія Ворожбіт-Горбатюк, доктор педагогічних наук, професор, професор кафедри освітології та інноваційної педагогіки Харківського національного педагогічного університету імені Г.С. Сковороди

Ольга Мельникова, кандидат педагогічних наук, доиент, доиент кафедри економічної теорії, фінансів і обліку Харківського національного педагогічного університету імені Г.С. Сковороди Ганна Кабанська, завідувач відділу практик Харківського національного педагогічного університету імені Г.С. Сковороди

\title{
НАУКОВО-ПЕДАГОГІЧНА ПРАКТИКА ЗДОБУВАЧІВ ДРУГОГО МАГІСТЕРСЬКОГО РІВНЯ ВИЩОЇ ОСВІТИ, СПЕЦІАЛЬНІСТЬ О51 ЕКОНОМІКА: ДОСВІД ХНПУ ІМЕНІ Г.С. СКОВОРОДИ
}

У статті авторами представлено досвід науково-педагогічної практики здобувачів другого магістерського рівня вищої освіти, спеціальність 051 Економіка, виділено иільові і змістові аспекти. Угруповано види і форми відповідного практикування, проаналізовано процесуальний аспект. Презентовано досвід формування компетентностей у здобувачів на етапі організаційнтх заходів, основному та підсумковому етапах практики.

Авторами представлено позицію здобувачів-практикантів про сильні сторони і перспективи оновлення програми науково-педагогічної практики за спеціальністю 051 Економіка.

Ключові слова: вища освіта; здобувач магістерського рівня; науково-педагогічна практика; спеціальність економіка.

Jim. 5.

Viktoriia Vorozhbit-Horbatiuk, Doctor of Science (Pedagogy), Professor, Professor of the Education and Innovative Pedagogy Department, Kharkiv Hryhoriy Skovoroda National Pedagogical University

Olga Melnykova, Ph.D.(Pedagogy), Associate Professor, Associate Professor of the Economic Theory, Finance and Accounting Department Kharkiv Hryhoriy Skovoroda National Pedagogical University Hanna Kabanska, Head of the Department of Practice Kharkiv Hryhoriy Skovoroda National Pedagogical University

\section{SCIENTIFIC AND PEDAGOGICAL PRACTICE OF SECOND MASTER LEVELS OF HIGHER EDUCATION, SPECIALTY O51 ECONOMICS: EXPERIENCE OF KHARKIV H.S. SKOVORODA NATIONAL PEDAGOGICAL UNIVERSITY}

The article presents the experience of organizing the scientific and pedagogical practice of applicants for the second master's level of higher education, specialty 051 Economics. The target and semantic aspects of the practice program are specified. It is noted: the priority of research practice of applicants for the second master's degree in higher education at Kharkiv H.S. Skovoroda National Pedagogical University is the focus on the formation of subject-methodological competence of economics, involvement in constructive cooperation with all departments of the university, organization of active research in cooperation with representatives of the academic community.

Taking into account the results of feedback from applicants, the types and forms of relevant practice are grouped, and proposals on the procedural aspect of the practice are analyzed.

Among the competencies that are formed in the process of practice, the article highlights the following: organizational - planning of educational, methodological, scientific and educational work in accordance with current regulations, ensuring interdisciplinary links of educational components; differentiation of the content of the discipline and teaching methods taking into account the requirements and expectations of the audience, development, conduct, an analysis of conducted and attended classes; participation in the control and accounting of applicants' knowledge; an analysis of educational and educational-methodical literature and its use for construction of own didactic content; application in modern information technologies, methods of teaching economic disciplines; development of motivation to study.

At the main stage of practice, the preparation of psychological and pedagogical characteristics of the academic group is provided. Educational work involves the participation of an undergraduate trainee in the preparation and conduct of a university or faculty event, the organization and conduct of extracurricular activities to promote the economy in the community or youth community.

(C) В. Ворожбіт-Горбатюк,

О. Мельникова, Г. Кабанська, 2021 
The final stage involves the preparation of presentational materials on the topic of master's research: abstracts of the report on the scientific-practical conference, the report on the scientific-pedagogical practice.

The authors present the position of applicants for practical strengths and prospects for quality updating of the program of scientific and pedagogical practice of applicants for the second master's level of higher education in the specialty 051 economics.

Keywords: higher education; master's degree; scientific and pedagogical practice; specialty economics.

П остановка проблеми у загальному вигляді та її зв'язок із важливими науковими чи практичними

завданнями. Питання практичного спрямування фахової вищої освіти вкрай значиме. Оскільки саме практична спрямованість освітнього процесу забезпечує формування фахових компетентностей і програмних результатів навчання, які визначають конкурентоспроможність випускника закладу вищої освіти на ринку праці. У світлі активних реформаційних процесів, які виразно прослідковуються у діяльності українських університетів, аналіз і презентування позитивного досвіду сприятиме формуванню необхідної критичної маси дослідження і згуртуванню академічної спільноти. Як наслідок - підвищення якості вищої освіти, можливість динамічного оцінювання поточних результатів діяльності науково-педагогічних працівників.

Аналіз основних досліджень і публікацій. Проблема практикування як необхідного складника фахової освіти не нова. У науковому просторі надзвичайно багато публікацій різного спрямування на означену тему. 3-поміж актуальних напрямів дослідження заявленої проблеми співзвучні матеріали публікації Л. Полещук (2020), де авторка акцентувала увагу на формуванні професійно значущих компетентностей під час практикування здобувачів у закладах вищої освіти [4]. Цікавими видаються міркування групи авторів Г. Дмитренко, Е. Помиткін, Н. Головач (2018) [1], оскільки в Харківському національному педагогічному університеті імені Г.С. Сковороди в освітньо-професійних програмах на самореалізації кожної особистості зроблено наголос.

Формування мети статті. Метою статті $\epsilon$ розкриття досвіду організації науково-педагогічної практики як обов'язкового складника освітньої програми другого магістерського рівня вищої освіти за спеціальністю "Економіка" у Харківському національному педагогічному університеті імені Г.С. Сковороди.

Виклад основного матеріалу дослідження. Науково-педагогічна практика у Харківському національному педагогічному університеті імені Г.С. Сковороди корелюється зі змістом освітньої програми підготовки фахівців другого магістерського рівня вищої освіти “Економіка бізнесу та фінансів", галузі знань 05 Соціальні та поведінкові науки спеціальності 051 Економіка [3].

Пріоритетними завданнями науково-педагогічної практики є формування у магістрантів фахових компетентностей і досвіду проведення різних видів занять зі здобувачами першого бакалаврського рівня вищої освіти, опанування і розширення загальних і фахових компетентностей знання та розуміння засад навчально-методичної, науковопедагогічної та виховної роботи у закладах вищої освіти, формування навичок дослідника і досвіду конструктивної співпраці з науково-педагогічними працівниками кафедр відповідного профілю в університеті, набуття досвіду науководослідницької і викладацької роботи в реальних умовах діяльності освітньої установи [5].

Досвід проходження науково-педагогічної практики магістрантами спеціальності 051 "Економіка" з використанням ресурсів дистанційного навчання у 2020-2021 навчальному році на базі Харківського національного педагогічного університету імені Г.С. Сковороди. Здобувачі другого магістерського рівня вищої освіти (галузь знань: 05 "Соціальні та поведінкові науки", спеціальності 051 "Економіка", факультет юридичний) проходили практику в умовах протиепідемічних заходів у закладах освіти на період карантину у зв'язку поширенням коронавірусної хвороби (COVID-19). Термін науково-дослідної практики: 305 до 31 жовтня 2020 p. Науково-педагогічна практика відбувалася дистанційно, на освітній платформі Moodle із використанням ресурсу онлайнконференцій Меet. Науковий керівник практики від факультету і з фаху - кандидат педагогічних наук, доцент, доцент кафедри економічної теорії, фінансів і обліку О. Мельникова, науковий керівник 3 психолого-педагогічних дисциплін - доктор педагогічних наук, професор, професор кафедри освітології та інноваційної педагогіки В. ВорожбітГорбатюк.

Виклики реалій освітнього процесу в умовах провадження карантинних заходів дали змогу здобувачам магістерського рівня вищої освіти освоїти новий формат організації освітнього процесу в університеті. Під час проходження науково-педагогічної практики у закладах вищої освіти на юридичному факультеті ХНПУ імені Г.С. Сковороди магістрантами виконано програму 
НАУКОВО-ПЕДАГОГІЧНА ПРАКТИКА ЗДОБУВАЧІВ ДРУГОГО МАГІСТЕРСЬКОГО РІВНЯ ВИЩОЇ ОСВІТИ, СПЕЦАЛЬНІСТЬ 051 ЕКОНОМІКА: ДОСВІД ХНПУ ІМЕНІ Г.С. СКОВОРОДИ

та реалізовано мету практики. На освітній платформі Moodle керівником від факультету доцентом О. Мельниковою розміщено необхідні навчальні, інформаційно-довідкові матеріали для здобувачів, окреслено вимоги до звітної документації про проходження науковопедагогічної практики, ознайомлено з процедурою оцінювання. Унікальність цьогорічного практикування у тому, що здобувачі змогли долучитися до проведення занять 3 навчальних дисциплін і реалізувати заплановані виховні заходи на освітній платформі Moodle із використанням ресурсу онлайн-конференцій Мeеt. Це - солідний досвід, який розкриває додаткові перспективи навчально-виховних, науково-дослідницьких комунікувань учасників освітнього процесу, опосередкованих ІКТ. Практиканти долучилися до роботи у статусі помічників педагога.

Значущим моментом в організації і здійсненні науково-дослідної практики здобувачів другого магістерського рівня вищої освіти в ХНПУ імені Г.С.Сковороди є триєдина структура усіх компонентів робочої навчальної програми, що узгоджено в логікою освітньої платформи дистанційної освіти MOODLE. За потребою $є$ можливість долучитися тим здобувачам, які потребують різних способів інклюзивної підтримки. Ця триєдина структура передбачає пріоритети в цілях і змісті. Так, на emani організаційно-інформаційному: формування у здобувачів другого магістерського рівня вищої освіти комплексу педагогічних компетентностей, зокрема: комунікативних, предметно-методичних, інформаційно-цифрових, психологічних, емоційноетичних, професійного педагогічного партнерства, організаційних, у тому числі - здатностей працювати в інклюзивномуі здоров'язбережувальному освітньому середовищі. Відкритість і позитивна атмосфера конструктивної співпраці науковопедагогічних працівників університету, профільних кафедри забезпечує вироблення у здобувачів магістерського рівня вищої освіти потреби систематично поповнювати знання та творчо застосовувати їх у практичній діяльності. Програма практики сформована таким чином, що здобувачі мають продемонструвати рівень систематизації і розуміння теоретичних знань, отриманих під час вивчення фахових дисциплін, їх практичне застосування в освітньому процесі закладу вищої освіти з урахуванням специфіки, особливостей, заявлених у нормативних i дорадчих документах. Здобувачі-практиканти долучаються організації та проведення занять із застосуванням актуальних технологій і методик навчання економічних дисциплін;
На основному змістовому етапі відбувається власне цілеспрямована робота $з$ оволодіння магістрантами сучасними методами і формами організації освітньої діяльності у закладах вищої освіти через включення їх до освітнього процесу (аудиторні заняття, самостійна навчальнопізнавальна діяльність, робота в наукових гуртках, участь в освітніх проєктах, виховних, іміджевих заходах на рівні університету і міжуніверситетської едукаційної активності). Магістранти, які проходили науково-педагогічну практику, вивчали вимоги до викладача, його обов'язки, правила і орієнтири професійної етики, ділової комунікації у цифровому просторі. На цьому етапі організовано роботу щодо ознайомлення, вивчення і долучення здобувачів до систематичного оновлення робочих навчальних програм освітніх компонент, методичного забезпечення курсів. Здобувачі також мали завдання оцінити матеріальнотехнічне забезпечення освітнього процесу в університеті. На цьому етапі засобами вербальної i невербальної комунікації організовано практикування щодо реалізації прогностичної компетентності: психолого-педагогічних спостережень, аналізу різних аспектів освітнього процесу в академічній групі з подальшою колективною рефлексією (рефлексивна компетентність). Власне, цей етап науковопедагогічної практики передбачає роботу щодо вироблення у здобувачів стійкого інтересу до обраної професії, стимулювання їх до вивчення фахових дисциплін, необхідних для подальшої професійної діяльності. Місія керівників і методистів - сприяти становленню у кожного практиканта індивідуального творчого стилю педагогічної діяльності (організаційна і оцінювально-аналітична компетентності).

На підсумковому етапі акцентується увага на формуванні і розвитку навичок дослідника, що власне реалізується наскрізною програмою підготовки магістерського дослідження. На цьому етапі здійснюється робота 3 формування інноваційної компетентності через презентування інноваційного продукту чи пропозиції за темою магістерського дослідження. Системою динамічного і формувального оцінювання результатів практики і науково-дослідницької роботи акумулюється здатність до навчання упродовж життя. Здобувачі-практиканти мають відкритий доступ до репозитарію університету, долучаються до участі в університетських, регіональних, національних, міжнародних наукових проєктах, академічних ініціативах, конференціях, отримують змогу в реаліях діяльності молодих науковців систематизувати матеріали наукового 
дослідження, презентувати їх як варіант оновлення навчально-методичного забезпечення освітніх компонент, підготувати і виступити з доповідями на наукових заходах.

Організаційно-інформаційна робота магістрантівпрактикантів в ХНПУ імені Г.С.Сковороди передбачає такі види робіт: участь у настановчій і підсумковій конференції як модератор чи спікер, участь в роботі наукового гуртка доповідачем чи учасником освітнього проєкту, участь в освітньому процесі на факультеті як помічника куратора. Оформлення і захист звіту про проходження науково-педагогічної практики.

Як бачимо, програмою науково-педагогічної практики у ХНПУ імені Г.С.Сковороди пердбачено системне ознайомлення магістарантів зі специфікою функціонування закладу вищої освіти, системи його управління; нормативно-правових засад діяльності структурних підрозділів університету, включення в роботу викладача економічних дисциплін, куратора академічної групи, моніторингу і вивчення особливостей студентів і академічних груп.

Провідною 3 підготовки фахівців за спеціальністю "Економіка" в ХНПУ імені Г.С. Сковороди $є$ кафедра економічної теорії, фінансів і обліку, (завідувачка - кандидат економічних наук, доцент В. Соляр) [2]. Науковопедагогічні працівники повною мірою реалізують студентоцентрований підхід, а саме: орієнтуються на систему ціннісних орієнтирів здобувачів, ретельно і розважливо використовують результати моніторингу і зворотного зв'язку зі здобувачами. Процесуальний аспект реалізації програми практики передбачає суворе дотримання позиції: кожен здобувач - неординарна особистість 3 високими креативними потенціями. За сприяння і підтримки науково-педагогічних працівників кафедри економічної теорії, фінансів і обліку здобувачі-практиканти відвідали засідання методологічного і методичного семінарів, проаналізували зміст навчально-методичних комплексів з економічних дисциплін, долучитися до підготовки наочних, роздаткових матеріалів для забезпечення освітнього процесу в умовах змішаного навчання. Формат відеоконференцій дав їм змогу оптимально організувати час практикування і відвідати навчальні заняття провідних викладачів факультету, студентівпрактикантів. Відкриті і показові заняття науковопедагогічних працівників кафедри були проаналізовані здобувачами-практикантами, досвід фахівців використано під час підготовки і проведення пробних і залікових занять 3 навчальних дисциплін “Педагогічний менеджмент”,
“Історія економіки та економічної думки”, “СC 3 класичної політичної економії”, “Фінанси”, “Бухгалтерський облік”. Практиканти також долучилися до виховної роботи на юридичному факультеті у новому форматі комунікування. Р. Біловус провів економічний квест в онлайнрежимі зі студентами-бакалаврами факультету, метою якого був розвиток економічного мислення сучасної молоді, формування фінансової культури. В. Біліченко ініцюював проведення брейн-рингу у форматі онлайн.

На підсумковій онлайн-конференції усі здобувачі-практиканти констатували високий рівень підготовки студентів бакалаврату, Я. Власенко акцентував увагу на сформованих соціально значимих навичках і високому рівні академічної підготовки за обраним фахом.

Висновки 3 даного дослідження i перспективи подальших розвідок у даному напрямку. Підсумовуючи викладене, зазначимо, що якісне оновлення програми науковопедагогічної практики у закладах вищої освіти передбачає активність магістрантів. Досвід ХНПУ імені Г.С. Сковороди свідчить, що для здобувачів така практика корисна і сприяє формуванню фахових компетентностей. Практично усі здобувачі висловилися про необхідність зміни формату звітування. Запропоновано виділити на освітній платформі окрему вкладку для відгуків і звороного зв'язку iз практикантами, де б вони могли поділитися досвідом, враженнями, емоціями від спілкування і освітніх взаємодій, зафіксованими на фото чи скріншотах. Також висловлено пропозицію щодо поліпшення матеріально-технічного оснащення кафедр і аудиторій факультету із залученням коштів меценатів. Здобувачі висловили побажання щодо формування навчальнометодичного комплексу науково-педагогічної практики з урахуванням можливостей і ресурсів освітньої платформи Moodle.

Результат проведення науково-педагогічної практики здобувачів другого магістерського рівня вищої освіти засвідчив, що дистанційний формат розкриває додаткові перспективи практичної підготовки фахівців, дає змогу оптимально організувати освітній процес, здійснювати наукову, навчальну, методичну і дослідницьку діяльність iз використанням популярних і IКТ.

Також визначено перспективні моменти, зокрема: розробка додаткових навчальних модулів, що не входять до навчальних планів освітніх програм за умови, якщо Виконавча Рада університету ініціюватиме подальшу сертифікацію отриманих додаткових компетенцій, 
підготовка і проведення майстер-класів, оновлення чинних навчальних програм для бакалаврів і магістрів на основі міждисциплінарного підходу (педагогіка-правознавство), підготовка і проведення творчих зустрічей та індивідуальних занять $з$ успішними здобувачами з метою пошуку талановитих і вмотивованих науковців.

\section{ЛІТЕРАТУРА}

1. Дмитренко Г., Помиткін Е., Головач Н. Формування здатних до самореалізації здобувачів освіти в умовах глобалізованого світу. Молодь $i$ ринок. Щомісячний науково-педагогічний журнал. Дрогобич, 2020. №1/180. С. 12 - 18.

2. Кафедра економічної теорії, фінансів і обліку Харківського національного педагогічного університету імені Г.С. Сковороди 2021. URL : http://hnpu.edu.ua/en/division/spivrobitnyky-kafedryekonomichnoyi-teoriyi-finansiv-i-obliku

3. Освітньо-професійнапрограма 051 "Економіка, управління та право” Харківський національний педагогічний університет імені Г.С. Сковороди. 2020. URL: http://smc.hnpu.edu.ua/files/ Osvitni_programi/Osvitni_programu magistr/ 2020 rik/Ekonomika upravlinnya ta pravo.pdf

4. Полещук Л. Педагогічні умови формування професійно-значущих якостей майбутніх менеджерів освіти. Молодь і ринок. Щомісячний науково-педагогічний журнал. Дрогобич, 2020. №6/ 185. С. $157-162$.

5. Положення про проведення практик у Харківському начіональному педагогічному університеті імені Г.С.Сковороди. 2017. URL: http://hnpu.edu.ua/sites/default/files/files/ Vidd_praktik/Pol_pro_prov_prakt_17_18.pdf

\section{REFERENCES}

1. Dmytrenko, H., Pomytkin, E. \& Holovach, N.
(2018). Formuvannia zdatnykh do samorealizatsii zdobuvachiv osvity v umovakh hlobalizovanoho svitu [Formation of self-fulfilling students in a globalized world]. Youth \& market. Monthly scientific and pedagogical journal. No. 1/180. pp. 12 - 18. [in Ukrainian].

2. Kafedra ekonomichnoi teorii, finansiv i obliku Kharkivskoho natsionalnoho pedahohichnoho universytetu imeni H.S. Skovorody (2021). [Department of Economik Theory, Finance and Accounting, H. S. Skovoroda. Kharkiv National Pedagogical University. Available at: http:// hnpu.edu.ua/en/division/spivrobitnyky-kafedryekonomichnoyi-teoriyi-finansiv-i-obliku [in Ukrainian].

3. Ocvitno-profesiina prohrama 051 "Ekonomika, upravlinnia ta pravo" (2020). [Educational and professional program 051 "Economics, Management and Law"]. H. S. Skovoroda Kharkiv National Pedagogical University. Available at: http:// smc.hnpu.edu.ua/files/Osvitni_programi/ Osvitni programu magistr/2020 rik/ Ekonomika_upravlinnya ta_pravo.pdf [in Ukrainian].

4. Poleshchuk, L. (2020). Pedahohichni umovy formuvannia profesiino-znachushchykh yakostei maibutnikh menedzheriv osvity [Pedagogical conditions of formation of professionally significant qualities of future managers of education]. Youth \& market. Monthly scientific and pedagogical journal. No. 6/185. pp. 157162. [in Ukrainian].

5. Polozhennia pro provedennia praktyk (2017). [Regulations on conducting practices]. H. S. Skovoroda Kharkiv National Pedagogical University. Available at: http://hnpu.edu.ua/sites/default/files/files/ Vidd_praktik/Pol_pro_prov_prakt_17_18.pdf [in Ukrainian].

Стаття надійшла до редакції 17.03.2021

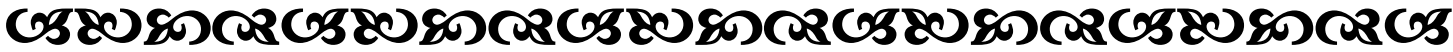

“Вченість - че солоджий плід гіркого кореня”.

Icoқpam

давнъогрецький боілособ

"Багато чого не зробиш, поқи не вивчишся. Але багато треба зробити, щоб навчитись".

Конбучій

давнъокитайський фбілософ

\section{G5808}

